\title{
Latitudinal variation of diversity in European freshwater animals is not concordant across habitat types
}

Hof, Christian; Brändle, Martin; Brandl, Roland

Published in:

Global Ecology and Biogeography

DOI:

10.1111/j.1466-8238.2008.00394.x

Publication date:

2008

Document version

Publisher's PDF, also known as Version of record

Citation for published version (APA):

Hof, C., Brändle, M., \& Brandl, R. (2008). Latitudinal variation of diversity in European freshwater animals is not concordant across habitat types. Global Ecology and Biogeography, 17(4), 539-546.

https://doi.org/10.1111/j.1466-8238.2008.00394.x 


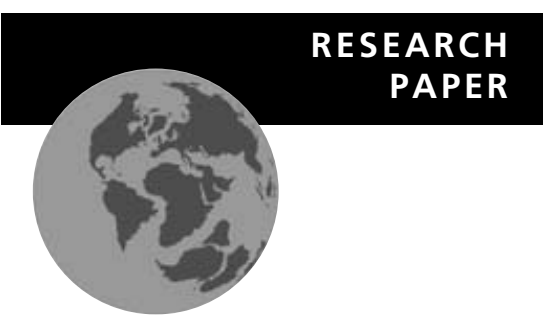

\title{
Latitudinal variation of diversity in European freshwater animals is not concordant across habitat types
}

\author{
Christian Hof ${ }^{1,3 \star}$, Martin Brändle $e^{1,2}$ and Roland Brandl ${ }^{1,2}$
}

${ }^{1}$ Department of Animal Ecology, Faculty of Biology, Philipps-Universität Marburg, Karl-von-Frisch-Strasse 8, 35032 Marburg,

${ }^{2}$ Virtual Institute Macroecology,

Theodor-Lieser-Strasse 4, 06120 Halle,

Germany, ${ }^{3}$ Present address: Center for

Macroecology, Department of Biology,

University of Copenhagen, Denmark;

Biodiversity and Global Change Lab,

Department of Biodiversity and Evolutionary

Biology, Museo Nacional de Ciencias Naturales,

Madrid, Spain

${ }^{*}$ Correspondence: Christian Hof, Biodiversity and Global Change Lab, Department of Biodiversity and Evolutionary Biology, Museo Nacional de Ciencias Naturales, Calle de José Gutiérrez Abascal, 2, 28006 Madrid, Spain. E-mail: chof@bio.ku.dk

\begin{abstract}
Aim We analysed the variation of species richness in the European freshwater fauna across latitude. In particular, we compared latitudinal patterns in species richness and $\beta$-diversity among species adapted to different habitat types.

Location Europe.

Methods We compiled data on occurrence for 14,020 animal species across 25 pre-defined biogeographical regions of European freshwaters from the Limnofauna Europaea. Furthermore, we extracted information on the habitat preferences of species. We assigned species to three habitat types: species adapted to groundwater, lotic (running water) and lentic (standing water) habitats. We analysed latitudinal patterns of species richness, the proportion of lentic species and $\beta$-diversity.

Results Only lentic species showed a significant species-area relationship. We found a monotonic decline of species richness with latitude for groundwater and lotic habitats, but a hump-shaped relationship for lentic habitats. The proportion of lentic species increased from southern to northern latitudes. $\beta$-Diversity declined from groundwater to lentic habitats and from southern to northern latitudes.

Main conclusions The differences in the latitudinal variation of species richness among species adapted to different habitat types are in part due to differences in the propensity for dispersal. Since lentic habitats are less persistent than lotic or groundwater habitats, lentic species evolved more efficient strategies for dispersal. The dispersal propensity of lentic species facilitated the recolonization of central Europe after the last glaciation. Overall, we stress the importance of considering the history of regions and lineages as well as the ecological traits of species for understanding patterns of biodiversity.
\end{abstract}

\section{Keywords}

$\beta$-Diversity, dispersal, Europe, freshwater, glaciations, history, latitude, species richness.

\section{INTRODUCTION}

Although it has been known about for more than 200 years, the decrease of species richness with latitude is still poorly understood (Fischer, 1960; for recent reviews see Willig et al., 2003; Hillebrand, 2004; Mittelbach et al., 2007). Besides the mid-domain effect (Colwell \& Lees, 2000), three classes of hypotheses have been proposed to explain this pattern: (1) the species-energy hypothesis, which states that species richness is determined by energy availability (Currie, 1991; Hawkins et al., 2003); (2) the species-area hypothesis, which points to the importance of space for species richness (Terborgh, 1973; Rosenzweig, 1995); and (3) the historical hypothesis which emphasizes the importance of history, in particular climatic fluctuations (Fischer, 1960; Dynesius \& Jansson, 2000; Graham et al., 2006). In Europe the climatic fluctuations during the Pleistocene had dramatic impacts on diversity patterns, since the east-west orientation of the major mountain ranges impeded rearrangements of distributional areas in response to climatic fluctuations (see, e.g., Whittaker et al., 2007, and references therein).

Habitat is an important template for the evolution of species traits, in particular for dispersal ability (Southwood, 1962; 1977). For freshwater ecosystems, studies initiated by I. Ribera and co-workers highlighted the importance of interactions between 
habitat stability, dispersal ability and patterns of species distributions (Ribera \& Vogler, 2000; Ribera et al., 2001, 2003; see also Hof et al., 2006; Marten et al., 2006; Ribera, 2008). Our study is an extension of this work covering a broader range of taxonomic groups and habitat types and analyzing $\beta$-diversity among biogeographical regions. It is, like the foregoing investigations, based on the following hypothetical framework: On geological time-scales lentic habitats (standing waters) are less stable than lotic (running waters) or groundwater habitats (Gibert et al., 1994; Dobson \& Frid, 1998; Griebler \& Mösslacher, 2003; Ribera, 2008). The majority of the larger lakes in Europe, for instance, date back to the Pleistocene (Schwoerbel, 1999). On the contrary, several European river systems originated in the Mesozoic (Hantke, 1993). Depending on size, lentic waters may even disappear within decades as sediments accumulate in the basins (Hutchinson, 1957; Harper, 1992). Overall, lentic habitats are likely to vanish within shorter periods of time than lotic habitats. Hence, one would expect species living in lentic habitats to be characterized by a higher propensity for dispersal than species living in lotic or groundwater habitats (Dobson \& Frid, 1998; Ribera \& Vogler, 2000; Ribera et al., 2003; Marten et al., 2006; Ribera, 2008).

From this, we deduce two predictions concerning latitudinal patterns of species richness and $\beta$-diversity in European freshwater animals. Firstly, if lentic species have a higher propensity for dispersal, they should have more rapidly recolonized central and northern regions. Hence we expect that species richness of lentic habitats should decrease with latitude at a lower rate compared with lotic or groundwater habitats. This implies also that the proportion of lentic species increases with latitude. Furthermore, dispersal influences species turnover ( $\beta$-diversity) (Soininen et al., 2007a,b). Therefore, we secondly expect lower levels of $\beta$-diversity among regions for lentic compared with lotic and groundwater species.

\section{METHODS}

The data for the present analyses were extracted from the Limnofauna Europaea (Illies, 1978). The biogeographical regions of Europe outlined in this book were used for all analyses (Table 1). For each region, data on latitude (northern and southern boundary), longitude (western and eastern boundary) and maximum altitude were compiled from http://earth.google.com/. From this information we calculated the mean latitude and longitude of each region. Areas of regions were estimated by weighing pieces of paper cut from a copied map. Note that four of the 25 regions are open at their eastern border, which may

Table 1 Geographical data and species richness of all habitats, and of the different habitat types of the 25 biogeographical regions of Europe as defined in the Limnofauna Europaea (Illies, 1978).

\begin{tabular}{|c|c|c|c|c|c|c|c|c|c|}
\hline \multirow[b]{2}{*}{$\begin{array}{l}\text { Region } \\
\text { code }\end{array}$} & \multirow[b]{2}{*}{ Region } & \multirow[b]{2}{*}{$\begin{array}{l}\text { Latitudinal } \\
\text { centre }\left({ }^{\circ} \mathrm{N}\right)\end{array}$} & \multirow[b]{2}{*}{$\begin{array}{l}\text { Longitudinal } \\
\text { centre }\left({ }^{\circ} \mathrm{E}\right)\end{array}$} & \multirow[b]{2}{*}{$\begin{array}{l}\text { Maximum } \\
\text { altitude (m) }\end{array}$} & \multirow[b]{2}{*}{$\begin{array}{l}\text { Area } \\
\left(\mathrm{km}^{2}\right)\end{array}$} & \multicolumn{4}{|c|}{ Species richness } \\
\hline & & & & & & $\begin{array}{l}\text { All } \\
\text { habitats }\end{array}$ & $\begin{array}{l}\text { Groundwater } \\
\text { habitats }\end{array}$ & $\begin{array}{l}\text { Lotic } \\
\text { habitats }\end{array}$ & $\begin{array}{l}\text { Lentic } \\
\text { habitats }\end{array}$ \\
\hline IBE & Ibero-Macaronesian region & 38.23 & -12.24 & 3717 & 560,736 & 2543 & 99 & 633 & 741 \\
\hline PYR & Pyrenees & 42.53 & 0.54 & 3404 & 49,548 & 1684 & 82 & 510 & 395 \\
\hline ITA & Italy, Corsica and Malta & 40.98 & 12.97 & 3380 & 264,311 & 3284 & 135 & 709 & 1018 \\
\hline ALP & Alps & 45.81 & 10.82 & 4808 & 210,580 & 4479 & 96 & 989 & 1426 \\
\hline DIN & Dinaric western Balkans & 44.37 & 17.71 & 2656 & 161,032 & 2543 & 170 & 683 & 682 \\
\hline HEL & Hellenic western Balkans & 39.13 & 23.76 & 2917 & 173,419 & 2258 & 100 & 566 & 729 \\
\hline $\mathrm{EAB}$ & Eastern Balkans & 41.73 & 25.07 & 2925 & 177,548 & 2161 & 74 & 564 & 623 \\
\hline WEH & Western highlands & 47.36 & 5.53 & 1886 & 156,903 & 2776 & 101 & 706 & 888 \\
\hline $\mathrm{CEH}$ & Central highlands & 49.74 & 12.50 & 1602 & 260,129 & 4922 & 133 & 927 & 1717 \\
\hline CAR & Carpathians & 47.15 & 22.07 & 2655 & 185,806 & 3842 & 130 & 884 & 1112 \\
\hline HUN & Hungarian lowlands & 46.48 & 19.72 & 500 & 169,290 & 3187 & 67 & 421 & 1098 \\
\hline PON & Pontic province & 45.83 & 30.18 & 1545 & 264,258 & 2819 & 50 & 345 & 939 \\
\hline WEP & Western plains & 46.90 & 0.61 & 1000 & 404,644 & 3690 & 106 & 609 & 1280 \\
\hline CEP & Central plains & 55.17 & 9.27 & 500 & 540,902 & 5465 & 77 & 627 & 2213 \\
\hline BAP & Baltic province & 56.93 & 24.23 & 318 & 210,580 & 3163 & 13 & 347 & 1263 \\
\hline EAP & Eastern plains & 53.48 & 38.66 & 1000 & $2,320,511$ & 3792 & 27 & 445 & 1442 \\
\hline IRE & Ireland and Northern Ireland & 53.39 & -8.01 & 1041 & 82,580 & 1669 & 9 & 249 & 691 \\
\hline GBR & Great Britain & 56.16 & -3.44 & 1344 & 235,354 & 3490 & 33 & 492 & 1350 \\
\hline ICE & Iceland & 64.91 & -19.02 & 2110 & 103,226 & 475 & 2 & 28 & 204 \\
\hline BOR & Borealic uplands & 64.13 & 13.06 & 2469 & 309,677 & 2153 & 4 & 276 & 1004 \\
\hline TUN & Tundra & 71.53 & 44.68 & 1590 & 330,219 & 1365 & 6 & 193 & 540 \\
\hline NSW & Northern Sweden & 64.60 & 17.44 & 1200 & 231,225 & 1954 & 12 & 254 & 849 \\
\hline TAI & Taiga & 63.03 & 39.71 & 1000 & $1,606,190$ & 2896 & 9 & 312 & 1221 \\
\hline $\mathrm{CAU}$ & Caucasus & 42.12 & 44.07 & 5642 & 363,354 & 2089 & 65 & 391 & 606 \\
\hline CAS & Caspic depression & 48.08 & 47.03 & 500 & 627,612 & 1591 & 5 & 144 & 532 \\
\hline
\end{tabular}


introduce some bias due to the distribution of singletons or the calculation of areas. All these areas are located in the European part of Russia. Therefore, we used the Ural Mountain chain as the eastern boundary of these regions. It is well known that the Ural Mountains act as a biogeographical boundary, which is not crossed by most of the species occurring in central Asia or Siberia.

For each region we compiled species presences or absences. The taxonomy as well as recent changes in species names were updated using the Fauna Europaea Web Service (2004). Our initial compilation listed 14,457 species, and after considering taxonomic changes and uncertain species the final list comprised 14,020 species of fish, annelids, water mites, crustaceans, insects, molluscs, nematodes, rotifers, flatworms and several taxa of fewer than 150 species (for an overview on species numbers of these major taxonomic groups, see Table S1 in Supplementary Material). The Limnofauna Europaea provides information of the habitat requirements for most of the species listed. From the more than 40 habitat categories given in the Limnofauna we grouped species into three major habitat types: groundwater, lotic (running waters from springs to large streams) and lentic habitats (standing waters from phytotelmata to large lakes). For a number of reasons we had to exclude $46 \%$ of the total species pool: (1) we had to exclude the 2663 species for which no habitat preferences where available; (2) we excluded 1958 generalists for which a habitat assignment was impossible; (3) we excluded 1025 parasitic species, as they rather rely on a specific host than on a certain type of habitat; (4) we excluded the 476 species occurring in brackish waters or with very special habitat requirements (e.g. leaf miners of aquatic plants, species living in mosses like tardigrades etc.).

Geographical variables and species richness of the different habitat types were tested for normality using the KolmogorovSmirnov test (StatSoft Inc., 2002). All variables except area approximated a normal distribution. Area was $\log _{10}$-transformed in all analyses, after which it also attained normality. We calculated simple linear regressions to test for the effect of area on species richness across the 25 regions. To analyse the relationship between species richness and latitude, we used multiple linear regressions. We always tested for the effect of latitude on species richness after correcting for all other geographical variables (for a visual inspection of the relationships between species richness and latitude, longitude, altitude and area see Fig. S1). The plot of species richness vs. latitude suggested a hump-shaped
Table 2 Slope and correlation coefficients for the relationship between species richness and area $\left(\log _{10}\right.$-transformed) for the three different habitat types (simple linear regressions, $n=25$ ).

\begin{tabular}{lcll}
\hline Habitat type & Slope & $R$ & $P$ \\
\hline Groundwater habitats & -29.16 & 0.044 & 0.32 \\
Lotic habitats & -48.58 & 0.0050 & 0.74 \\
Lentic habitats & +537.4 & 0.19 & 0.031 \\
\hline
\end{tabular}

relationship. Therefore, we also included squared latitude as an independent variable in some analyses. To investigate the relationship between the proportion of lentic species and latitude, we used a multiple generalized linear model (binomial error term, logit link function, forward selection; Crawley, 2002). Patterns of $\beta$-diversity among regions were investigated by means of additive partitioning of species diversity (Crist et al., 2003) for each of the three habitats. For this analysis, regions were grouped into four latitudinal bands according to their latitudinal centres $\left(<45^{\circ} \mathrm{N}\right.$, between $45^{\circ} \mathrm{N}$ and $50^{\circ} \mathrm{N}$, between $50^{\circ} \mathrm{N}$ and $60^{\circ} \mathrm{N},>60^{\circ} \mathrm{N}$; see Fig. 2). Areas of regions were used as weights.

\section{RESULTS}

We found a significant species-area relationship only for lentic habitats (Table 2). The relationship of species richness and latitude differed between lentic habitats compared with lotic and groundwater habitats. In the latter species groups, species richness declined monotonically with latitude, whereas lentic species exhibited a hump-shaped relationship (Table 3, Fig. 1, Fig. S2). Species richness of lentic species peaked in central Europe, within a region covering the Netherlands, the northern part of Germany, the southern part of Scandinavia and parts of Poland (region CEP, see Table 1 and Fig. 2). The proportion of lentic species increased significantly from southern to northern latitudes (deviance $=647.2, P<0.0001$; Fig. 3 ). Even after considering the other geographical variables this pattern remained significant (Table 4). Additive partitioning of species diversity revealed a decline of $\beta$-diversity from groundwater to lotic to lentic species (Fig. 2). Furthermore, for each of the three habitat types, $\beta$-diversity decreased from southern to northern latitudes (Fig. 2).
Figure 1 Relationship between latitude and species richness for freshwater species occurring within three different habitat types: (a) groundwater habitats, (b) lotic habitats, (c) lentic habitats. Each point represents the number of species occurring in the respective habitat within one of the 25 regions shown in Fig. 2.
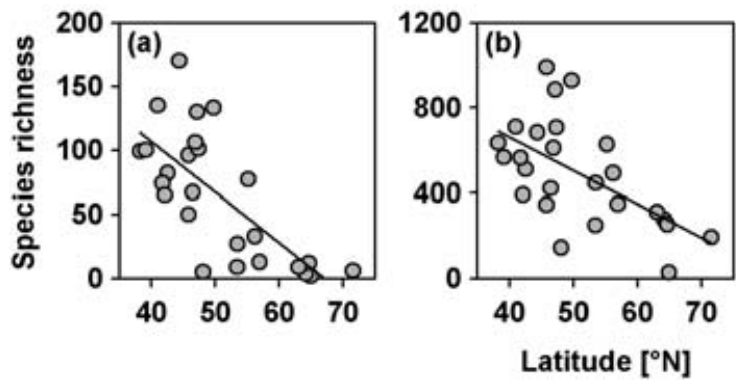

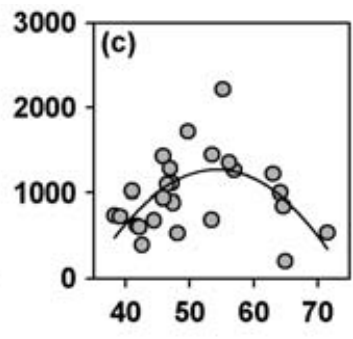


Table 3 Multiple linear regressions of species richness for freshwater animals within 25 European biogeographical regions vs. geographical variables (type I sum of squares; StatSoft Inc., 2002) according to different habitat types. Significant relationships are indicated in bold.

\begin{tabular}{|c|c|c|c|c|c|c|c|c|c|}
\hline & $\beta$ & MSS & $F$ & $P$ & & $\beta$ & MSS & $F$ & $P$ \\
\hline \multicolumn{5}{|c|}{ Groundwater habitats } & \multicolumn{5}{|c|}{ Lentic habitats } \\
\hline Area & 0.001 & 2589 & 1.7 & 0.206 & Area & 0.48 & 894,966 & 6.8 & 0.017 \\
\hline Longitude & -0.13 & 557 & 0.37 & 0.551 & Longitude & -0.18 & 289,230 & 2.2 & 0.154 \\
\hline Altitude & 0.14 & 9485 & 6.3 & 0.021 & Altitude & -0.037 & 225,321 & 1.7 & 0.206 \\
\hline Latitude & 0.37 & 19,174 & 12.7 & 0.002 & Latitude & 5.4 & 73,866 & 0.56 & 0.462 \\
\hline Latitude $^{2}$ & -1.0 & 349 & 0.23 & 0.636 & Latitude $^{2}$ & -5.4 & 820,983 & 6.3 & 0.022 \\
\hline Residuals & & 1510 & & & Residuals & & 131,343 & & \\
\hline \multicolumn{10}{|c|}{ Lotic habitats } \\
\hline Area & 0.15 & 7008 & 0.16 & 0.690 & & & & & \\
\hline Longitude & -0.17 & 39,051 & 0.91 & 0.352 & & & & & \\
\hline Altitude & 0.31 & 222,965 & 5.2 & 0.034 & & & & & \\
\hline Latitude & 2.8 & 289,894 & 6.8 & 0.018 & & & & & \\
\hline Latitude $^{2}$ & -3.3 & 90,277 & 2.1 & 0.163 & & & & & \\
\hline Residuals & & 42,815 & & & & & & & \\
\hline
\end{tabular}

MSS, mean sum of squares; $\beta$, standardized regression coefficient.
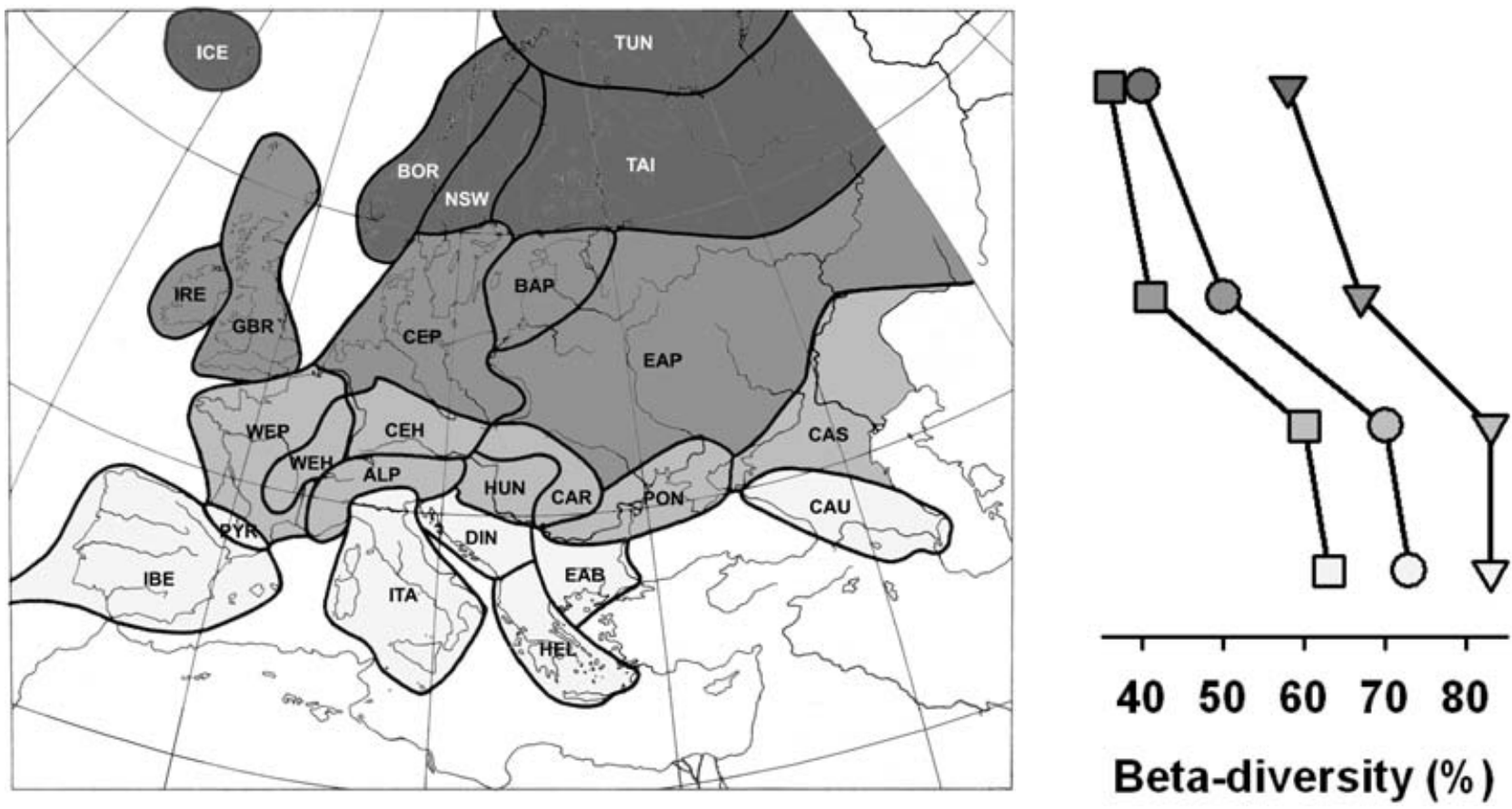

Figure $2 \beta$-Diversity of freshwater animals within four bands of regions across Europe. We calculated $\beta$-diversity for each band and habitat using additive partitioning of species richness (Crist et al., 2003). A value of $100 \%$ would indicate that all species occur in only one region of a band and a value of $0 \%$ that all species occur in all regions of a band. Regions of a band are marked by the same colour. $\beta$-Diversity decreased from groundwater species to lentic species for all four bands and $\beta$-diversity decreased with latitude for all habitat types (square, lentic habitats; circle, lotic habitats; triangle, groundwater). Region codes are listed in Table 1.

\section{DISCUSSION}

Our analyses showed (1) a monotonic decline of species richness with latitude for groundwater and lotic habitats, but a humpshaped relationship for lentic habitats; (2) an increase in the proportion of lentic species with increasing latitude; and (3) a decline in $\beta$-diversity from groundwater to lotic to lentic habitats and from southern to northern latitudes.
The observed patterns in species richness might be caused by a variation in the sampling effort among regions (Bardgett et al., 2005; Moerman \& Estabrook, 2006). As many, if not most, ecologists and taxonomists reside in central Europe, the fauna of this region is very well known (Illies, 1966; Bardgett et al., 2005). We argue that this bias does not sufficiently explain the observed variation of richness. First, since the fauna of groundwater habitats is not very well known (Gibert et al., 1994; Griebler \& 


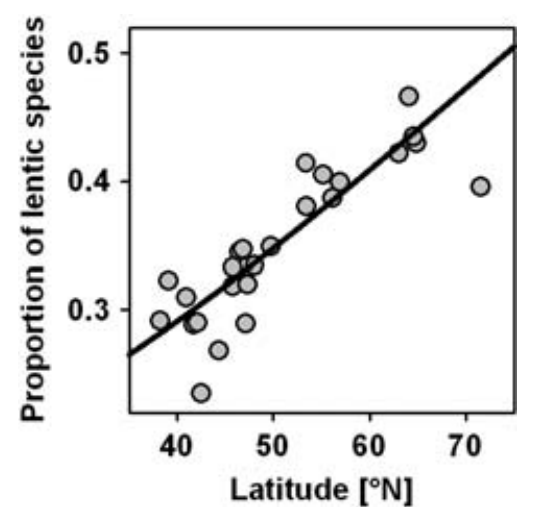

Figure 3 Proportion of lentic species in relation to latitude. Each point represents the proportion of species occurring in lentic habitats of the 25 regions shown in Fig. 2. The curve visualizes a generalized linear model $($ deviance $=647.2 ; P<0.0001$; $\left.y=e^{-1.93+0.026 \times \text { latitude }}\left(1+e^{-1.93+0.026 \times \text { latitude }}\right)^{-1}\right)$.

Table 4 Relationships between the proportion of lentic species within 25 biogeographical regions of Europe vs. geographical variables (multiple generalized linear model, binomial error term, logit link function, forward selection, Crawley, 2002, $n=25$ ).

\begin{tabular}{lccl}
\hline & Estimate & Deviance & $P$ \\
\hline Area & 0.13 & 134 & $<0.001$ \\
Longitude & -0.0029 & 16.9 & $<0.001$ \\
Altitude & -0.000028 & 238 & $<0.001$ \\
Latitude & 0.037 & 324 & $<0.01$ \\
Latitude $^{2}$ & -0.00013 & 1.03 & 0.31 \\
\hline
\end{tabular}

Mösslacher, 2003), sampling should particularly influence the species numbers within this group. However, species richness of the groundwater fauna declined with latitude (Fig. 1a). Second, the number of species recorded in only one sample (singletons) is a good indicator of the sampling effort (Novotný \& Basset, 2000). In our case the number of singletons in a region has two components: species with a restricted geographical range (endemics) and species accidentally recorded in only one region. The latter is an indication of the sampling effort. If the hump-shaped pattern is a consequence of the extensive sampling in central Europe, then we would expect: (1) that species groups with a hump-shaped relationship have a high proportion of singletons; and (2) that there is also a hump-shaped relationship between the number of singletons and latitude. However, the hump-shaped relationship occurs in species adapted to lentic habitats (Table 3, Fig. 1c), which have a rather low proportion of singletons compared with lotic and groundwater species (Table S2). Furthermore, for all three species groups the number of singletons declines with increasing latitude (Fig. S3).

Although the areas of the biogeographical regions differed by a factor of more than 40 (Table 1), area was a poor predictor of species richness for species adapted to lotic and groundwater habitats. One may argue that terrestrial surface area is not a good surrogate for area covered by freshwaters. For groundwater habitats, though, the terrestrial surface area roughly approximates habitat area, as groundwater is a type of freshwater habitat that should be available almost everywhere below the surface (Gibert et al., 1994; Griebler \& Mösslacher, 2003). However, for groundwater species, the relationship between species richness and area was negative (Table 2). If one accepts that our failure to find a species-area relationship for groundwater or lotic habitats is not due to a bias, the difference in the significance between lotic and lentic habitats becomes interesting. A non-significant relationship between area and species richness may be due to nonequilibrium conditions (MacArthur \& Wilson, 1963; Ricklefs \& Bermingham, 2004), which points to differences in the equilibrium conditions between groundwater and lotic vs. lentic biota. We will return to this point below.

Many papers have documented that species richness increases with several surrogates of energy available to the communities of plants or animals (Wright, 1983; Currie, 1991; Badgley \& Fox, 2000; Hawkins et al., 2003). Even if the geographical resolution of our data is not sufficient for a meaningful evaluation of the energy-availability hypothesis, the monotonic decline of species richness with latitude that was observed for lotic and groundwater habitats is consistent with a latitudinal decline of energy availability. Nevertheless, the surprising difference in the latitudinal variation of species richness among species adapted to different habitats rejects the energy-availability hypothesis as a general explanation.

We are aware of four possible explanations for the observed differences in diversity patterns among habitats: (1) evolutionary idiosyncrasies; (2) differences in habitat availability; (3) differences in the location of refugia; and (4) differences in the dispersal propensity of species among habitats. These are discussed in turn below.

(1) We pooled a wide variety of taxa with very different phylogenetic backgrounds. This could lead to differences in diversity patterns between habitats if certain taxa of species adapted to a particular habitat dominate certain regions. To investigate if such evolutionary idiosyncrasies are responsible for the decrease of species richness with latitude in lotic and groundwater habitats, we tested whether the observed correlations are expected by chance, i.e. whether the phylogenetic assignment drives the pattern. For this, we randomized habitat preference across species and calculated the correlation coefficient for the relationship between species richness and latitude (for a detailed explanation see Fig. S4). For both lotic and groundwater habitats, the correlation coefficient expected by chance was negative, but all simulated coefficients were larger than the observed coefficients. Consequently, evolutionary idiosyncrasies are not sufficient to explain the decrease of species richness with latitude.

(2) The availability of the habitat types across the 25 biogeographical regions might also explain the observed differences in the latitudinal variation of species richness. This argument is partly related to our discussion of the species-area relationship. For groundwater habitats, terrestrial area approximates the available 
habitat area. Our failure to find a species-area relationship for this habitat type suggests that the availability of habitats is not sufficient to explain the diversity patterns of freshwater species. Ribera et al. (2003) also argued consistently against this habitatavailability hypothesis. Nevertheless, further investigations are needed for a convincing test of this hypothesis.

(3) After the last glaciation many species recolonized central Europe from Mediterranean refugia (de Lattin, 1957; Hewitt, 1999). However, recent studies have demonstrated the existence of glacial refugia north of the Alps (Stewart \& Lister, 2001; Pauls et al., 2006; Kristjánsson \& Svavarsson, 2007). Furthermore, a considerable number of species may have colonized central Europe from eastern regions (e.g. Banarescu, 1990; Kotlík et al., 2004). Irrespective of the location of the refugia, the recolonization of Europe should be biased towards species with a high dispersal propensity. The decrease of $\beta$-diversity from southern to northern regions may also be a legacy of the recolonization of the higher latitudes after the Pleistocene (Hewitt, 1999; 2000).

(4) Lentic species are assumed to show a higher propensity for dispersal than lotic species. The differences in $\beta$-diversity among species adapted to groundwater, lotic and lentic habitats are perfectly consistent with the proposed differences in the dispersal propensity of species associated with these habitats, because with an increasing propensity for dispersal one expects a decrease in $\beta$-diversity (Soininen et al., 2007a,b). From this, in turn, one may deduce the hypothesis that the decrease of species richness with latitude in lotic as well as groundwater habitats is due to a low recolonization rate. The increase in the proportion of lentic species with latitude supports this argument. Consequently one might argue that the communities of lotic and groundwater habitats have not yet reached equilibrium in central and northern Europe. In contrast, lentic species may have reached equilibrium, which is also suggested by a significant species-area relationship (see above). Furthermore, low dispersal rates facilitate speciation (Bohonak, 1999; Marten et al., 2006), which should lead to a higher speciation rate in lotic as well as groundwater species compared to lentic species (Ribera \& Vogler, 2004). The rugged topographic relief of the Mediterranean regions may have further contributed to a higher speciation rate (Mayr, 1942; Hewitt, 1999). The high levels of $\beta$-diversity in southern Europe are concordant with a higher speciation rate in the Mediterranean. However, we found this difference in lotic and lentic species. Therefore, differences in the speciation rate of lentic and lotic species do not sufficiently explain the observed difference in the relationship between species richness and latitude among lentic and lotic species.

None of these four factors that may have influenced the difference in the relationship between species richness and latitude among the different habitat types can account for the hump in species richness of lentic freshwater animals in central Europe. We propose three possible processes that might have generated this pattern. First, a considerable number of lentic species could have gone extinct in the southern refugia after the last glaciation, when the Mediterranean climate shifted to semi-arid conditions (Salinas et al., 2000; Oliva-Paterna et al., 2003). Note that this argument is not consistent with the foregoing, that habitat availability is not supposed to drive the observed patterns. Second, if lentic species are stronger dispersers, more species from eastern refugia may have reached central Europe. At the end of the last Ice Age, huge proglacial lakes provided pathways of recolonization for lentic species (e.g. Schäfer, 1997). However, our data indicate a decrease in the proportion of lentic species from west to east (Table 4). Consequently, this explanation also seems to be rather unlikely. Third, the mid-domain effect predicts a hump in species richness in the centre of a geographical domain (Colwell \& Lees, 2000). This model places geographical ranges of species randomly across the available space. Furthermore, it assumes that biota are close to equilibrium. Indeed, due to their higher dispersal ability, lentic species should be near equilibrium conditions (see also above), so the mid-domain effect might be useful to approach an explanation of the species richness peak in lentic species in central Europe.

With our study, we underline that to understand differences in the spatial variation of biological diversity among taxa one has to consider the history of regions and lineages (Graham et al., 2006; Rahbek et al., 2007; Reyjol et al., 2007; Svenning \& Skov, 2007) as well as the ecological traits of species (Ribera et al., 2003; Vogler \& Ribera, 2003; Hof et al., 2006; Marten et al., 2006; McPherson \& Jetz, 2007; Ribera, 2008). Furthermore, our analyses support previous studies which document that various European groups of plants and animals are not in equilibrium with current climate (Svenning \& Skov, 2004; Araújo \& Pearson, 2005; Araújo et al., 2008).

\section{ACKNOWLEDGEMENTS}

We thank, in particular, David G. Jenkins for comments on an earlier draft of this manuscript. Thanks to Miguel B. Araújo, Carsten Rahbek and Andreas Marten for inspiring discussions. Yorick Reyjol, Katrin Böhning-Gaese and two anonymous referees provided helpful remarks on the submitted manuscript. The Cusanuswerk - the German Catholic Scholarship Foundation - provided financial support for C.H. Finally, we are particularly grateful to the freshwater biologists who compiled the data for the Limnofauna Europaea.

\section{REFERENCES}

Araújo, M.B. \& Pearson, R.G. (2005) Equilibrium of species' distributions with climate. Ecography, 28, 693-695.

Araújo, M.B., Nogués-Bravo, D., Diniz-Filho, J.A.F., Haywood, A.M., Valdes, P.J. \& Rahbek, C. (2008) Quaternary climate changes explain diversity among reptiles and amphibians. Ecography, 31, 8-15.

Badgley, F. \& Fox, D.L. (2000) Ecological biogeography of North American mammals: species density and ecological structure in relation to environmental gradients. Journal of Biogeography, 27, 1437-1467.

Banarescu, P. (1990) Zoogeography of fresh waters. General distribution and dispersal of freshwater animals. AULA Verlag, Wiesbaden. 
Bardgett, R.D., Yeates, G.W. \& Anderson, J.M. (2005) Patterns and determinants of soil biological diversity. Biological diversity and function in soils (ed. by R.D. Bardgett, M.B. Usher and D.W. Hopkins), pp. 100-118. Cambridge University Press, Cambridge.

Bohonak, A.J. (1999) Dispersal, gene flow, and population structure. Quarterly Review of Biology, 74, 21-45.

Colwell, R.K. \& Lees, D.C. (2000) The mid-domain effect: geometric constraints on the geography of species richness. Trends in Ecology and Evolution, 15, 70-76.

Crawley, M.J. (2002) Statistical computing. An introduction to data analyses using S-Plus, 1st edn. Wiley, Chichester, UK.

Crist, T.O., Veech, J.A., Gering, J.C. \& Summerville, K.S. (2003) Partitioning species diversity across landscapes and regions: a hierarchical analysis of alpha, beta, and gamma diversity. The American Naturalist, 162, 734-743.

Currie, D.J. (1991) Energy and large-scale patterns of animal- and plant-species richness. The American Naturalist, 137, 27-49.

Dobson, M. \& Frid, C. (1998) Ecology of aquatic systems. Longman, Harlow.

Dynesius, M. \& Jansson, R. (2000) Evolutionary consequences of changes in species' geographical distributions driven by Milankovitch climate oscillations. Proceedings of the National Academy of Sciences USA, 97, 9115-9120.

Fauna Europaea Web Service (2004) Fauna Europaea, version 1.1. Available online at http://www.faunaeur.org.

Fischer, A.G. (1960) Latitudinal variations in organic diversity. Evolution, 14, 64-81.

Gibert, J., Danielopol, D.L. \& Stanford, J.A. (1994) Groundwater ecology. Academic Press, San Diego.

Graham, C.H., Moritz, C. \& Williams, S.E. (2006) Habitat history improves prediction of biodiversity in rainforest fauna. Proceedings of the National Academy of Sciences USA, 103, 632636.

Griebler, C. \& Mösslacher, F. (2003) Grundwasserökologie. Facultas, Vienna.

Hantke, R. (1993) Flussgeschichte Mitteleuropas. Ferdinand Enke Verlag, Stuttgart, Germany.

Harper, D. (1992) Eutrophication of freshwaters. Chapman \& Hall, London.

Hawkins, B.A., Field, R., Cornell, H.V., Currie, D.J., Guégan, J.F., Kaufman, D.M., Kerr, J.T., Mittelbach, G.G., Oberdorff, T., O’Brien, E.M., Porter, E.E. \& Turner, J.R.G. (2003) Energy, water, and broad-scale geographic patterns of species richness. Ecology, 84, 3105-3117.

Hewitt, G.M. (1999) Post-glacial re-colonization of European biota. Biological Journal of the Linnean Society, 68, 87-112.

Hewitt, G.M. (2000) The genetic legacy of the Quaternary ice ages. Nature, 405, 907-913.

Hillebrand, H. (2004) On the generality of the latitudinal diversity gradient. The American Naturalist, 163, 192-211.

Hof, C., Brändle, M. \& Brandl, R. (2006) Lentic odonates have larger and more northern ranges than lotic species. Journal of Biogeography, 33, 63-70.

Hutchinson, G.E. (1957) A treatise on limnology. Wiley, New York.
Illies, J. (1966) Verbreitung der Süßwasserfauna Europas. Verhandlungen der Internationalen Vereinigung für Theoretische und Angewandte Limnologie, 16, 287-296.

Illies, J. (1978) Limnofauna Europaea, 2nd edn. Gustav Fischer Verlag, Stuttgart.

Kotlík, P., Bogutskaya, N.G. \& Ekmekçi, F.G. (2004) Circum Black Sea phylogeography of Barbus freshwater fishes: divergence in the Pontic glacial refugium. Molecular Ecology, 13, 87-95.

Kristjánsson, B.K. \& Svavarsson, J. (2007) Subglacial refugia in Iceland enabled groundwater amphipods to survive glaciations. The American Naturalist, 170, 292-296.

de Lattin, G. (1957) Die Ausbreitungszentren der holarktischen Landtierwelt. Verhandlungen der Deutschen Zoologischen Gesellschaft Hamburg, 1956, 380-410.

MacArthur, R.H. \& Wilson, E.O. (1963) An equilibrium theory of insular zoogeography. Evolution, 17, 373-387.

McPherson, J.M. \& Jetz, W. (2007) Effects of species' ecology on the accuracy of distribution models. Ecography, 30, 135-151.

Marten, A., Brändle, M. \& Brandl, R. (2006) Habitat type predicts genetic population differentiation in freshwater invertebrates. Molecular Ecology, 15, 2643-2651.

Mayr, E. (1942) Systematics and the origin of species. Columbia University Press, New York.

Mittelbach, G.G., Schemske, D.W., Cornell, H.V., Allen, A.P., Brown, J.M., Bush, M.B., Harrison, S.P., Hurlbert, A.H., Knowlton, N., Lessios, H.A., McCain, C.M., McCune, A.R., McDade, L.A., McPeek, M.A., Near, T.J., Price, T.D., Ricklefs, R.E., Roy, K., Sax, D.F., Schluter, D., Sobel, J.M. \& Turelli, M. (2007) Evolution and the latitudinal diversity gradient: speciation, extinction and biogeography. Ecology Letters, 10, 315-331.

Moerman, D.E. \& Estabrook, G.F. (2006) The botanist effect: counties with maximal species richness tend to be home to universities and botanists. Journal of Biogeography, 33, 1969-1974.

Novotný, V. \& Basset, Y. (2000) Rare species in communities of tropical insect herbivores: pondering the mystery of singletons. Oikos, 89, 564-572.

Oliva-Paterna, F.J., Miñnano, P.A. \& Torralva, M. (2003) Habitat quality affects the condition of Barbus sclateri in Mediterranean semi-arid streams. Environmental Biology of Fishes, 67, 13-22.

Pauls, S.U., Lumbsch, H.T. \& Haase, P. (2006) Phylogeography of the montane caddisfly Drusus discolor: evidence for multiple refugia and periglacial survival. Molecular Ecology, 15, 2153-2169.

Rahbek, C., Gotelli, N.J., Colwell, R.K., Entsminger, G.L., Rangel, T.F.L.V. \& Graves, G.R. (2007) Predicting continental-scale patterns of bird species richness with spatially explicit models. Proceedings of the Royal Society B: Biological Sciences, 274, 165-174.

Reyjol, Y., Hugueny, B., Pont, D., Bianco, P.G., Beier, U., Caiola, N., Casals, F., Cowx, I., Economou, A., Ferreira, T., Haidvogl, G., Noble, R., de Sostoa, A., Vigneron, T. \& Virbickas, T. (2007) Patterns in species richness and endemism of European freshwater fish. Global Ecology and Biogeography, 16, 65-75.

Ribera, I. (2008) Habitat constraints and the generation of diversity in freshwater macroinvertebrates. Aquatic insects: 
challenges to populations (ed. by J. Lancaster and R.A. Briers). CAB International, Wallingford, UK (in press).

Ribera, I. \& Vogler, A.P. (2000) Habitat type as a determinant of species range sizes: the example of lotic-lentic differences in aquatic Coleoptera. Biological Journal of the Linnean Society, 71, 33-52.

Ribera, I. \& Vogler, A.P. (2004) Speciation of Iberian diving beetles in Pleistocene refugia (Coleoptera, Dytiscidae). Molecular Ecology, 13, 179-193.

Ribera, I., Barraclough, T.G. \& Vogler, A.P. (2001) The effect of habitat type on speciation rates and range movements in aquatic beetles: inferences from species-level phylogenies. Molecular Ecology, 10, 721-735.

Ribera, I., Foster, G.N. \& Vogler, A.P. (2003) Does habitat use explain large scale species richness patterns of aquatic beetles in Europe? Ecography, 26, 145-152.

Ricklefs, R.E. \& Bermingham, E. (2004) History and the speciesarea relationship in Lesser Antillean birds. The American Naturalist, 163, 227-239.

Rosenzweig, M.L. (1995) Species diversity in space and time. Cambridge University Press, Cambridge, UK.

Salinas, M.J., Blanca, G. \& Romero, A.T. (2000) Riparian vegetation and water chemistry in a basin under semiarid Mediterranean climate, Andarax River, Spain. Environmental Management, 26, 539-552.

Schäfer, A. (1997) Biogeographie der Binnengewässer. B. G. Teubner, Stuttgart.

Schwoerbel, J. (1999) Einführung in die Limnologie. Gustav Fischer Verlag, Jena, Germany.

Soininen, J., Lennon, J.J. \& Hillebrand, H. (2007a) A multivariate analysis of beta diversity across organisms and environments. Ecology, 88, 2830-2838.

Soininen, J., McDonald, R. \& Hillebrand, H. (2007b) The distance decay of similarity in ecological communities. Ecography, 30, 3-12.

Southwood, T.R.E. (1962) Migration of terrestrial arthropods in relation to habitat. Biological Reviews, 37, 171-214.

Southwood, T.R.E. (1977) Habitat, the templet for ecological strategies. Journal of Animal Ecology, 46, 337-365.

StatSoft Inc. (2002) STATISTICA for Windows, Version 6.1 (http:// www.statsoft.com).

Stewart, J.R. \& Lister, A.M. (2001) Cryptic northern refugia and the origins of the modern biota. Trends in Ecology and Evolution, 16, 608-613.

Svenning, J.C. \& Skov, F. (2004) Limited filling of the potential range in European tree species. Ecology Letters, 7, 565-573.

Svenning, J.C. \& Skov, F. (2007) Ice age legacies in the geographical distribution of tree species richness in Europe. Global Ecology and Biogeography, 16, 234-245.

Terborgh, J. (1973) On the notion of favorableness in plant ecology. The American Naturalist, 107, 481-501.

Vogler, A.P. \& Ribera, I. (2003) Evolutionary analysis of species richness patterns in aquatic beetles: why macroecology needs a historical perspective. Macroecology: concepts and consequences (ed. by T.M. Blackburn and K.J. Gaston), pp. 17-30. Blackwell, Oxford. Whittaker, R.J., Nogués-Bravo, D. \& Araújo, M.B. (2007) Geographical gradients of species richness: a test of the water- energy conjecture of Hawkins et al. (2003) using European data for five taxa. Global Ecology and Biogeography, 16, 76-89.

Willig, M.R., Kaufman, D.M. \& Stevens, R.D. (2003) Latitudinal gradients of biodiversity: pattern, process, scale, and synthesis. Annual Review of Ecology Evolution and Systematics, 34, 273-309.

Wright, D.H. (1983) Species-energy theory: an extension of the species-area theory. Oikos, 41, 496-506.

\section{SUPPLEMENTARY MATERIAL}

The following supplementary material is available for this article:

Table S1 Taxonomic groups included in the analyses.

Table S2 Habitat types used in the Limnofauna Europaea.

Figure S1 Relationships between species richness and geographical variables.

Figure S2 Relationships between latitude and residuals of the regression of species richness and area.

Figure S3 Relationships between number of singletons and latitude.

Figure S4 Distribution of simulated correlation coefficients of the relationship between species richness and latitude for randomized habitat preference.

This material is available as part of the online article from: http://www.blackwell-synergy.com/doi/abs/10.1111/ j.1466-8238.2008.00394.x

(This link will take you to the article abstract).

Please note: Blackwell Publishing is not responsible for the content or functionality of any supplementary materials supplied by the authors. Any queries (other than missing material) should be directed to the corresponding author for the article.

\section{BIOSKETCHES}

Christian Hof is broadly interested in biodiversity research, particularly in the fields of macroecology, biogeography and conservation biology. Parts of this study were part of his MSc thesis at the Department of Animal Ecology of the University of Marburg. He is now a PhD student at the Center for Macroecology of the University Copenhagen, where he investigates the impacts of climate change on global biodiversity.

Martin Brändle works in the fields of biogeography, macroecology and population genetics. His recent research focuses on genetic diversity of freshwater invertebrates and diversity patterns of phytophagous insects on trees.

Roland Brandl has broad interests in ecology, particularly in large-scale patterns of genetic and species diversity.

Editor: Katrin Böhning-Gaese 